\title{
Prevalence of Iron, Folic Acid and Vitamin B12 Deficiency in Patients with Thalassemia Minor
}

\author{
Suheyl Asma ${ }^{1}$, Cigdem Gereklioglu ${ }^{1}$, Ahmet Ferit Erdogan ${ }^{1}$, Mahmut Yeral ${ }^{2}$, Mutlu Kasar ${ }^{2}$, \\ Can Boga ${ }^{2}$, Hakan Ozdogu ${ }^{2}$ \\ ${ }^{1}$ Department of Family Medicine, Baskent University Faculty of Medicine, Adana/Turkey \\ ${ }^{2}$ Department of Hematology, Baskent University Faculty of Medicine, Adana/Turkey
}

\section{ÖZET}

Talasemi Minor'da Demir, Folik Asit ve B12 Eksikliği Prevalansı

Talasemi taşıyıcılığına bağlı anemi bölgemizde sık karşılaşılan hematolojik bir problemdir ve demir eksikliği anemisi ile karışabilmektedir. Her ikisinin birlikte olduğu olgularda anemi daha da derinleşmesine rağmen konu ile ilgili kaynaklarda bilgiler yeteri kadar açık değildir. Bu çalışma, beta talasemi taşıyıcılığı tanısı alan hastaların besinsel durumunu (demir, folik asit ve vitamin B12) değerlendirmesi amacıyla yapılmıştır. Çalışmaya beta talasemi taşıyıcılığı tanısı almış alan 47'si erkek toplam 183 hasta alındı. Kadın hastaların \%17.5 sinde ve erkeklerin \% 1.6'sinde demir eksikliği olduğu tespit edildi. Vitamin B12 ve folik asit düşüklüğü sırasıyla \%28.7, \%10.3 olarak saptandı. Çalışmamız sonucunda takip edilen talasemi taşıyıcılığında eşlik eden demir eksikliği ve diğer besinsel anemilerin (vitamin b12 ve folik asit eksikliği) varlığının araştırılmasının yararlı olabileceği düşünülmektedir.

Anahtar Kelimeler: Beta Talasemi Minor, Demir Eksikliği Anemisi, B12 Vitamini, Folik Asit

\section{ABSTRACT}

Prevalence of Iron, Folic Acid and Vitamin B12 Deficiency in Patients with Thalassemia Minor

Thalassemia trait -related anemia is a common hematologic problem in Mediterranean region. This type of anemia may be frequently confused with iron deficiency anemia. Anemia becomes more severe in case of coexistence of both anemia types and literature knowledge is sparse on that issue. This study was carried out with the aim of investigation of iron, folic acid and vitamin B12 levels in patients who were diagnosed with beta thalassemia trait. A total of 183 patients (47 male, 136 female) who were diagnosed with beta thalassemia minor were enrolled in the study. Iron deficiency was detected in $17.5 \%$ of women and in $1.6 \%$ of men. Decreased vitamin B12 and folic acid values were detected as $28.7 \%$ and $10.3 \%$, respectively. It was concluded that serum iron, folic acid and vitamin B12 levels should also be measured in assessment of talassemia trait patients due to its high prevalence in study region.

Key Words: Beta Thalassemia Minor, Iron Deficiency Anemia, Vitamin B12, Folic Acid

Asma S, Gereklioglu C, Erdogan AF, Yeral M, Kasar M, Boga C, Ozdogu H. Prevalence of iron, folic acid and vitamin B12 deficiency in patients with thalassemia minor. TJFMPC 2013;7(4):83-86. DOI: 10.5455/tjfmpc.41116

\section{Introduction}

Beta thalassemia are types of inherited autosomal recessive blood diseases caused by insufficient beta chain synthesis of hemoglobin leading to chronic haemolysis and severe anemia. Beta thalassemia trait means heterozygous form of this

Corresponding author:

Dr. Süheyl Asma; Başkent University Adana Research Center, 01220 Adana

e-mail: asma_asma2000@yahoo.de

Tel: +90 32232727 27-2063

Fax: +903223285159

Received Date: July 16, 2013

Accepted Date: November 05, 2013 disease characterized by mild anemia. ${ }^{1,2}$ The rate of beta thalassemia with a high $\mathrm{HbA} 2$ reported as $3.4 \%$ overall in the South of Turkey and highest (7.1\%) among the Kurdish speaking people. ${ }^{2}$

Iron deficiency anemia is present in more than 1.5 billion individuals worldwide. ${ }^{3}$ Iron deficiency is the most common cause of anemia in the South of Turkey with the prevalance of $17.2 \%$ overall. $^{2}$ Although the most common cause of iron deficiency is iron loss due to menstrual bleeding, long standing gastrointestinal hemorrhages are also one of the most important causes of iron deficiency. It is also an important problem seen due to complications of chronic diseases and in pregnancy. ${ }^{3,4}$ 
If co-existance of beta thalassemia trait and nutritional deficiencies such as iron, vitamin B12 and folic acid develop in a patient, anemia will be expected as more severe. ${ }^{5,6}$ So, it is important to recognize, diagnose and treat vitamin B12 and folic acid deficiency-related anemias. The current knowledge concerning nutritional deficiencies in patients with beta thallasemia trait is not clear. In this study, it was aimed to investigate iron, folic acid and vitamin B12 status in patients with beta thalassemia trait.

\section{Material and Method}

The study represents a retrospective, crosssectional, single-center cohort study. Data were collected from a previously authorized and validated Hospital Information Management System (Nucleus version 9.6.37, Monad, Ankara, Turkiye). The validity of the data was checked by the Record Inspection Group of the related Department.

A total of 183 patients (136 female, 47 male) with beta thalassemia trait between January 2006 and September 2011 and who were not receiving iron, vitamin B12 or folic acid therapy were included in the study. Complete blood count was analysed using Cell Dyn 37000 (Abbott Park, IL, USA) in all patients. Patients whose $\mathrm{Hb} \mathrm{A} 2$ was between 3.50$10.0 \%$ on High pressure liquid chromatography (HPLC) and whose mean corpuscular volume (MCV) was $<80 \mathrm{fl}$, mean corpuscular hemoglobin (MCH) was $<27$ pg were diagnosed with beta thalassemia trait; patients whose serum iron was $<60 \mu \mathrm{g}(60-140$ $\mu \mathrm{g})$ and saturation index was $<20 \%(20-55)$, ferritin was $<7 \mathrm{ng} / \mathrm{mL}(7-140 \mathrm{ng} / \mathrm{mL})$ were diagnosed with iron deficiency anemia. Reference range of vitamin B12 was determined as $179-883 \mathrm{pg} / \mathrm{mL}$ with Chemiluminescent Microparticle Immunoassay using Arcitect device (Abbott Laboratories, Abbott Park, IL, USA), reference range of folic acid was determined as 3-17 ng/dL for folic acid.

Patients whose ferritin levels were elevated as acute phase reactant or who had inflammatory diseases and other haemoglobinopathies were excluded from the study.

\section{Statistics}

Obtained data were analysed using SPSS 17.0 statistical package program. Mann-Whitney $U$ test and Pearsons Chi-Square test were used.

A P level of $<0.05$ was accepted as statistically significant.

\section{Results}

Table 1 represents clinical and laboratory characteristics of patients with beta thalassemia trait.

A total of 183 patients with thalassemia trait (47 $\mathrm{M}, 136 \mathrm{~F}$ ) were included in the study. Most of the subjects were female $(74,4 \%)$ with mean age of $48,0 \pm 17,6$ years (range 17-86). When we compared clinical and laboratory parameters by female versus male patients, we observed female patients had lower hemoglobin and more incidence of nutritional deficiency (hgb 10.4 vs 11.4 , iron deficiency $32(\% 23.5)$ vs $3(\% 6.3), p<$ 0.05 for all). Majority of subjects $89,1 \%$ had a hemoglobin $\mathrm{F}$ level of $\leq 2 \%$ and $10.9 \%$ of subjects had a hemoglobin $\mathrm{F}$ level of $>2 \%$. Serum vitamin B12 level was found as $<179 \mathrm{pg} / \mathrm{mL}$ in 45 out of 157 patients (28.7\%) whose vitamin B12 level was studied. Vitamin $B 12$ values were $\geq 179 \mathrm{ng} / \mathrm{ml}$ in most of the male and female patients.

Table 2 shows a comparison of hematological parameters of patients with beta thalassemia trait according to presence of iron deficiency anemia.

Out of 183 subjects, $\% 19,1$ had iron deficiency anemia. Of the patients who were detected to have iron deficiency anemia, 17,5\% were female and $1,6 \%$ were male. Hemoglobin and MCV were statistically significantly lower and $\mathrm{MCH}$ and RDW levels were statistically significantly greater in iron deficient subjects $(P<0.05)$. Mean eryhtrocyte counts did not differ between the groups.

No significant difference was found between MCV of cases with normal or low B12 level. Similarly no difference was detected between MCV of cases with normal or low folic acid level. Folic acid deficiency $(<3 \mathrm{ng} / \mathrm{dL}$ ) was detected in 15 out of 145 patients $(10,3 \%)$.

\section{Discussion}

Prevalence of talassemia trait is around $2,1 \%$ in Turkey. This ratio is as high as $13 \%$ in some regions including Meditteranean, Agean and Trachian regions. ${ }^{7}$ Several ethnic groups living in this area may have played a role in developing thalassemic cases due to marriage between close relatives. ${ }^{2}$ Nutritional deficiencies like iron, and vitamin B12 are also frequent in people living in these areas. ${ }^{2,8}$ 
Table 1. Clinical and laboratory characteristics of patients with beta thalassemia trait

\begin{tabular}{|c|c|c|}
\hline Characteristics & Iron def.n(\%) & Vit B12 def. $\mathbf{n}(\%)$ \\
\hline Male & $3(6,3)$ & $33(28,2)$ \\
\hline Female & $32(23,5)$ & $45(28,6)$ \\
\hline Total & $35(19,1)$ & \\
\hline
\end{tabular}

İron def: iron deficiency, Vit B12 def: vitamin B12 deficiency

Table 2. Comparison between the subjects with or without iron deficiency anemia

\begin{tabular}{|l|l|l|l|}
\hline Parameters & $\begin{array}{l}\text { With IDA (SF <7) } \\
\text { Mean } \pm \text { SD (range) }\end{array}$ & $\begin{array}{l}\text { Without IDA (SF } \geq 7) \\
\text { Mean } \pm \text { SD (range) }\end{array}$ & P value \\
\hline Hemoglobin (g/dl) & $10,0 \pm 1,4(6,8-12,8)$ & $11,5 \pm 1,5(8,4-15,6)$ & $<0,01$ \\
\hline MCV (fl) & $60,1 \pm 5,2(51,0-72,1)$ & $64,8 \pm 4,2(53,2-81,0)$ & $<0,01$ \\
\hline MCH(pg) & $19,3 \pm 2,6(15,0-28,1)$ & $21,0 \pm 1,5(17,2-27,3)$ & $<0,01$ \\
\hline RDW (\%) & $19,8 \pm 2,6(16,0-25,7)$ & $17,6 \pm 1,8(14,8-26,6)$ & $<0,01$ \\
\hline
\end{tabular}

IDA: iron deficiency anemia, SD: standart deviation

The prevalence of iron deficiency using low transferring saturation as criteria was found to be $17.2 \%$ overall. $^{2}$ Dietary habit, and probably helicobacter infection may have resulted in nutritional deficiency. ${ }^{8,9}$

The patient with thalassemia trait usually have a mild microcytic anemia and they are usually asymptomatic. Microcytosis may lead to confusion with iron deficient state. So, these patients sometimes receive unnecessary iron. However those patients should not use iron unless iron deficiency develops. Folic acid treatment is recommended as some patients may develop folic acid deficiency. ${ }^{10,11}$

Knowing iron levels is of importance in thalassemia trait cases. Hemoglobin levels in stable period may be detected in thalassemia trait cases that do not have iron deficiency. Ferritin levels would decrease in case of iron deficiency and hypochromic microcytic anemia would become more overt. Patients need iron therapy in this case. ${ }^{5,12,13}$ The evaluation of iron status in Iranian adults in 2000 showed that beta thalassemia minor may play a role in improving iron status in females. However in men, iron supplementation can lead to iron overload. They concluded that, iron level should be examined in subjects with the trait especially in men, to avoid harmful effects of iron overload in early stages of the disorder. ${ }^{6}$ In a previous study conducted with 150 beta thalassemia trait, prevalence of iron deficieny was found as $29,7 \%$ in females and $3,4 \%$ in males. ${ }^{14}$ In our study, prevalence of iron deficiency was found as $17,5 \%$ in females and $1,6 \%$ in males with thalassemia trait cases suggesting females tend to have more blood loss in menstrual periods or they have more pica habit like phagophagia comparing with males. These observations are supported by our previously published reports. ${ }^{9,12}$ As expected, the hemoglobin, MCV of iron deficient patients were lower while $\mathrm{MCH}$ and RDW levels were significantly greater values. A significant difference was not found in erythrocyte count.

The most important findings of vitamin B12 and folic acid deficiency are morphologic changes in bone marrow and blood. Megaloblastic anemia develops due to impaired DNA synthesis. ${ }^{15,17}$ Morphological changes in peripheral blood include macrocytosis and hypersegmentation of neutrophils.

In our study, prevalence of vitamin B12 and folic acid deficiency among patients with thalassemia trait were detected as $28.7 \%$ and $10.3 \%$, respectively. These percentages are very impressive and they might be a reflection of the effect of $\mathrm{H}$. pylori infection on serum vitamin B12 level. Higher frequency of vitamin B12 deficiency was reported in a study from Meditteranean 
region of Turkey compared with a western study. The study showed a strong association of vitamin B12 deficiency with Helicobacter pylori infection. ${ }^{18}$ Another study conducted with patients responsive to vitamin B12 treatment, hematoctrit values were detected to fall below $25 \%$ in only $20 \%$ of patients with thalassemia trait. ${ }^{16}$ In our study, no difference was found between patients whose vitamin B12 level was low or normal in terms of MCV. Erythrocyte volume elevations may be masked by coexisting iron deficiency or thalassemia trait. Therefore normal MCV levels may be seen in one-thirds of patients with vitamin B12 deficiency. ${ }^{15,16}$

In conclusion, nutritional deficiency like iron, vitamin B12 and folic acid for individuals with beta thalassemia trait in some regions of Turkey remains elusive. An epidemiologic study seems necessary due to the phenotypic variability of patients with thalassemia trait who have nutritional problem.

\section{References}

1.Guvenc B, Canataroglu B, Unsal C, Yıldız SM, et al. Arch Med Sci 2012;8 (3): 411-4

2.Koçak R, Alpaslan ZN, Ağrıdağ G, Baslamıslı F, et al. Eur J Epidemiol 1995;11(2)181-4.

3. Hershko C, Konijn AM, Loria A. Serum ferritin and mean corpuscular volume measurement in the diagnosis of beta-thalassaemia minor and iron deficiency. Acta Haematol 1979;62(4):236-9.

4. Hercberg S, Preziosi P, Galan P: Iron deficiency in Europe. Public Health Nutr 2001;4(2B):537-45.

5.Clarke R, Grimley EJ, Schneede J, et al. Vitamin B12 and folate deficiency in later life. Age Ageing 2004;33.34-41.

6.Hoorfar H, Sadrarhami S, Keshteli AH, Ardestani SK, Ataei M, Moafi A. Evaluation of iron status by serum ferritin level in Iranian carriers of beta thalassemia minor. Int J Vitam Nutr Res 2008;78(4,5):204-207.

7.Genc A, Tasdemir KD, Urhan KM, et al. Prevalence of beta-thalassemia trait and abnormal hemoglobins in the province of Adıyaman, Turkey. Pediatr Hematol Oncol 2012;29(7):620-3.

8.Kocak R, Paydas S. Pernicious anemia in Turkey. Int J Hematol 1992;55(2):117-9.

9.Asma S, Boga C, Ozdogu H, Serin E. The association of phagophagia with Helicobacter pylori infection in patients with iron deficiency anemia. Int J Hematol 2009;90(1):28-32.

10.Kosch M, Schaefer RM: Indications and practical management of parenteral iron therapy. Wien Klin Wochenschr 2003 24;115(11):380-4.

11.Froom P, Aghai E, Quitt M, Yechiely H, Kahana L. Folate status in beta-thalassemia minor. Isr J Med Sci 1985;21(10):845-6.

12.Asma S, Boga C, Ozdogu H. Safety, therapeutic effectiveness and cost of parenteral iron therapy. Int J Hematol 2009;90(1):24-7.

13.Andrews NC: Disorders of iron metabolism. Blood, editors: Handın RI, Lux SE, Stossel TP, Lippincott Williams and Wilkins, Philadelphia, 2. Edt 2002; p:1400

14.Tuphan KD, Nataraj. Prevalence of iron deficiency in thalassemia minor. A study from Tertiary Hospital. Indian J Hematol Blood Transfus 2012;28(1):7-9.

15.Röth A. Megaloblastaere Anaemien. Herold G. In: Innere Medizin. Gerd Herold, Köln. 2007: 27-31. 16.Mazzone A, Vezzoli M, Ottini E. Masked deficit of $B(12)$ and folic acid in thalassemia. Am J Hematol 2001;67(4):274.

17.Crayn, Elizabeth MD. Vitamin B12 deficiency; recognition and management. Primary Care Case Reviews 2002;5(2):53-60.

18.Gümürdülü $Y$, Serin $E$, Özer $B$, Kayaselçuk $F$. Predictors of vitamin B12 deficiency: age and Helicobacter pylori load of antral mucosa. Turk J Gastroenterol2003;14(1):44-9. 